\title{
Restless Heart: Towards an Existential Ontology of Eros in Augustine
}

\author{
Jeffrey Centeno
}

\section{ABSTRACT}

St. Augustine's famous prayer in the Confessions, "You have made us for yourself, and our heart is restless until it rests in you," remains today an indispensable resource of philosophical reflection. We can draw from it, particularly its understanding of eros, in our quest for meaning in our increasingly changing world. In a rapidly transforming world, the fundamental questions of being human, like cultural solidarity, human sexuality, and integral spirituality, can take on new meanings, thus requiring contemporary understanding. The existential longing for self-meaning lies at the core of philosophical reflection. Meaning is necessarily reflexive; it constitutes the sense of being oneself within the context of manifold relations. This paper concludes with the assertion that a renewed understanding of eros in our human situation can help enhance our understanding of human sexuality and its inextricable relation to integral spirituality.

KEY WORDS: happiness, human person, love, philosophy, sexuality, spirituality

"On the scales of God, only hearts have any weight." (Rahner, Behold the Heart 330)

\section{INTRODUCTION}

This article aims to develop a renewed understanding of sexuality as an integral aspect of being human, in the light of Saint Augustine of Hippo's (354-430 AD) analysis of eros.

Our search for meaning necessarily presupposes an integral understanding of who we are as human beings. This implies a holistic approach 
to the fundamental dimensions of being human, among which is the reality of sexuality which permeates our whole being. Sexuality individualizes as well as constitutes the ontology of every human person. Sexuality further implies a situated and gendered thinking. This definitely opens up vast possibilities to constantly interpret and to envision love and its manifold expressions from a wide range of perspectives, in response to the enduring challenge of being human. This concern has had a rich history in the history of thought, which remains today an important source of serious reflection.

Our intention in this article is to recover Augustine's enduring insight into the meaning of eros, specific to human beings as desiring beings. It is hoped that one's personal reflections on this insight would increase the level of our appreciation of the role of eros in our lives. Moreover, greater insight into the nature of eros is imperative, as our failure to understand sexuality has serious implications on our relationships. "Most of the pitfalls in social ethics, political theory, and education are due to a misunderstanding of the ontological character of love," observes Paul Tillich (24) in Love, Power, and Justice. There is no neglecting the role of love, sex, and eros in our everyday existence. As we shall see, Augustine's philosophy and theology illustrates well this role of eros in our everyday relationships.

However, one may ask, why bring someone like Augustine, from the $5^{\text {th }}$ century and the late Roman Empire, to the $21^{\text {st }}$ century? He would seem a rather odd resource for us in the present. However, as Paula Fredriksen observes, "We still live with the consequences of Augustine's theology" (68). Through Augustine's work, we get an important glimpse of a period in antiquity, focused on (and hoping for) reconciling secular thought with Christianity in the final days of the Roman Empire, which may be relevant to our own present struggles.

More importantly, through Augustine, we gain an insight into the classical culture in which he lived, which, notwithstanding the temporal distance, held the same human aspiration of total well-being as we do in the present. Martin Heidegger calls this historical bridging between different periods "de-distancing." As Heidegger explains in Being and Time, "Da-sein is spatial by way of circumspectly discovering space so that it is related to beings thus spatially encountered by constantly de-distancing" (100).

There is much wisdom in the words of Augustine, who continues to cast a long shadow across contemporary philosophy, theology, and literature. Jostein Gaarder, author of the bestselling novel Sophie's World, has Augustine as a central figure in his moving tale Vita Brevis: A Letter to Augustine. He describes Augustine as "probably the pre-Renaissance individual who 
is closest to ourselves" (4). Arguably, much of the resurgence of religion in postmodern Continental thought traces its inspiration to Augustine.

We are familiar with what is perhaps the most quoted line in all of Augustine's works: "You have made us for yourself, and our heart is restless until it rests in you" (Confessions I: 1). It speaks of the human longing for enduring meaning in the face of all that is fleeting. Indeed, for Augustine, the desire to be a fulfilled or successful human person flows from the primeval nature of unity or harmony, to which all our being ultimately tends and eventually returns. "Such do I desire to be" (X: 34, 52). Philosophy, conceived as the clearest manifestation of rational life, functions to return the human person to a unified wholeness. The attainment of this ultimate unity brings about the "healing of our humanity," as Plato suggests in the Symposium. This conclusion is also found in Augustine's philosophy, testifying to his Platonic influence.

Our following reflection on Augustine's philosophy of eros should lead to a renewed understanding of human sexuality as a necessary condition for gaining a better understanding of our embodied existence. The relevance of Augustine's philosophy will remain as long as there are people who continue to reflect on the meaning of human life and its various dimensions-especially on the dimension of sexuality. Philosopher Sam Keen captures this relevance in his book The Passionate Life:

Love, sexuality, and power can only be healed by returning to the original meaning of eros: by seeing the pleasures of the flesh within the context of a vision of the human promise, as it unfolds over the course of a lifetime within the ambience of the community and the cosmos.... Our erotic potential is fulfilled only when we become cosmopolitan lovers, only when potentia (power) and eros (desire) reunite our bodies to the polis (the body politic) and the cosmos (the natural environment). (5)

In the preceding discussion, we established the continuing relevance of Augustine's thought to our understanding of eros. However, we have yet to unpack Augustine's understanding of eros, and thus propose that we follow the following presuppositions for our present investigation:

1. existential ontology refers to the process of building our sense of humanity on the ground of Being;

2. eros, in light of existential ontology, primordially describes the reality of human transcendence that gives birth to, and sustains the life of, philosophy; and, 
Jeffrey Centeno, "Towards an Existential Ontology of Eros in Augustine"

3. Augustine is a key example in the development of the understanding of eros, henceforth described in this work as the self's primordial search for its other.

\section{EXISTENTIAL ONTOLOGY}

The challenge of being necessarily includes grappling with the question of our sexuality, which is co-extensive with our own existence. Recognizing the problem it poses to philosophy, Jean-Paul Sartre, in his magnum opus Being and Nothingness, asserts:

Is sexuality a contingent accident bound to our physiological nature, or is it a necessary structure of our being-for-itself-for-others? From the sole fact that the question can be posited in these terms, we see that we must go back to ontology to decide it. (499)

Sartre's formulation of the problem is quite useful for our purposes, as it takes the discussion of sexuality beyond the typical physio-biological treatment of sexuality, which tends to reduce the human person to an object.

Therefore, ontology, around which the purported mastery of the sciences over the world ultimately clusters, must be the center of reference in any investigation of human sexuality. Ontology reveals the greater reality of human existence within which the issue of human sexuality can be properly seen, discussed, and appreciated.

Through ontology, sexuality is revealed as a specific mode of human existence in a world of relations. Being a man or a woman distinctly shapes and permeates our way of life. Thinking is necessarily embodied, and the Cartesian cogito is, in truth, embedded in human sexuality. Human awareness cannot be separated from our embodied experience of the world. "[E]mbodied awareness is giving rise to an ethic based on eros, a somatic, intuitive form of agency in which empathy, compassion, and care are the central moral qualities," Linda Holler asserts in her work Erotic Morality (1). We see from this statement that embodied human sexuality is an ontological issue that grounds the moral dimension, dwelling on the question of facticity.

Hannah Arendt writes, "[h] uman life exists in relatedness to Being" (53), pointing out that anthropological questions find their conclusion in the ontological condition. That is to say, the human person, the only being that asks about its own existence, seeks ontological answers to his search for meaning. "Seeking-Being-through-meaning" encapsulates the whole process of existential ontology. 
This can mean that the quality of human existence-or to use a term we used above, total well-being-refers to an active life that progressively moves towards its existential goal. "Man's search for meaning is the primary motivation in his life and not a 'secondary rationalization' of instinctual drives," asserts Viktor Frankl (121). Hence, this suggests a life led in conscious effort to break new grounds of meaning and to fulfill the call of human flourishing. This involves actualizing one's highest potential, with a view to expanding one's universe. However, the quality of human existence finds its origin in the unmistakable reality of Being. It is from the standpoint of Being that the human search for meaning becomes worthwhile. Yet, the way to the question of Being passes through an investigation of the meaning of being human.

Martin Heidegger is instructive as far as this point is concerned. In Being and Time, Heidegger writes, "fundamental ontology, from which alone all other ontologies can originate, must be sought in the existential analysis of Da-sein" (11). The path towards the Being of beings necessarily takes the course of the human situation itself. For out of the hermeneutical situation the human person seeks to understand him/herself in relation to what is good, true, and beautiful. (Pseudo-Dionysius is to have said: "Eros is the necessary correlate of Being, Good, and Beautiful.") Da-sein is Heidegger's notion of the givenness of the human being seeking authentic existence in a world of relations grounded in Being.

One can conclude from the preceding discussion that the human search for meaning is actually a yearning for Being. This yearning for Being can also be framed as a yearning for an ultimate end, or telos. In other words, the teleology of human life reaches its ground in ontology. This is a crucial claim. Indeed, if human existence were all teleological, like a series of projects to attain with no final end to aspire for, then it loses its meaning. This includes the rightful place of our experience of bodily pleasure. Pleasure for pleasure's sake, say, from sensual passions, brings about in the end a feeling of emptiness, and ironically, a sense of dissatisfaction in the same pleasure one initially sought.

Pleasures, bodily or otherwise, must be seen as indicators or "signals of transcendence," a term borrowed from the sociology of religion. This can be seen, too, in clinical questions. Consider a case in existential psychology. In one clinical case of schizophrenia, referred to as the case of Mrs. R, the psychoanalyst R.D. Laing makes the following observation: "(Mrs. R.)'s sexual life and phantasies were efforts, not primarily to gain gratification, but to seek first ontological security" (57). 
Thus, there must be a constructive end to complete the whole process of searching and founding one's humanity that builds beyond the foundation of earthly goods, including the legitimate pleasures of sex. Thus, the human person, in search of existential purpose amidst life's travails, hopes to find and rest in the Truth around which all finite meanings cluster. "Is not the life of man upon earth a trial, without any relief whatsoever?" (Augustine, Confessions X: 28, 39).

\section{EROS AND PHILOSOPHY}

"The impetus to philosophy lies in our very nature as rational inquirers: as beings who have questions, demand answers, and want these answers to be as cogent as the circumstances allow," explains Nicholas Rescher (68). Rescher's description of philosophy as essentially linked to human rationality summarizes the recognition of eros as the foundation of Western thought. That is, the history of Western philosophy is the history of eros. Why? Philosophy as "love of wisdom," a passion for knowledge, or a search for truth, ultimately implies the desire to connect, to relate, and to be complete. Eros is our desire for wholeness; it implies a life seeking integration with all there is. That makes philosophy essentially metaphysical, since it strives to make sense of the whole of reality in the face of appearances.

The idea of wholeness reveals a holistic meaning of the challenge of achieving unity in diversity. On an ethical count, this also means that the wholeness we seek can only be mediated through our relational experience of oneness with one another. This is eros. Allan Bloom is most articulate on this point. As he puts it in Love and Friendship, philosophy is a "privileged form of Eros.... [For it is a way of life] dedicated to finding out the things that are most important for the human person to know" (432). This implies a life in pursuit of truth, because truth is the real object of every authentic inquiry. One's relation to the truth is constitutive of the life of philosophy.

Philosophy thus consists in searching for and achieving the full purpose of existence. This definitely suggests how it is to be a philosopher, if one is ready for it. Bloom continues: "Socrates [is] the most erotic of philosophers" (431). We can surmise that Socrates' being the epitome of eros has to do with his courage to risk everything for the sake of something greater. Moreover, he was convinced that he had to spread this knowledge and teach others in order to open their minds. David McNeill eloquently puts it this way:

Like Eros, Socrates is characterized by a seemingly limitless capacity for generating discourses while in conversation with others, a peculiar resource- 
fulness which seems to be connected with his ability to divine what kinds of education are appropriate for different kinds of human souls" (265).

Socrates' lifestyle was an exemplary example of the philosophical life. With Socrates, philosophy's focus shifted to the study of the human person.

The shift to studying the meaning of being human reoriented the whole Western philosophical enterprise. Unlike the Eastern way of thinking, which has long accepted the function of philosophy as a practical guide to life, Western thought only embraced the ethical impetus with the Socratic injunction to "know thyself." With Socrates' unforgiving questioning, searching for and touching on the heart of human existence, we can affirm Bloom's claim that "philosophy is the most complete and most revealing form of Eros" (544). Using today's catch term "deconstruction," we can pursue the matter further by claiming that Socrates deconstructed "logos" with eros.

For the ancient Greeks, eros is the cosmic principle that sustains all things. It is the force or principle that leads the eternal in the human person to the home it has longed for in a blissful return. Prior to the rise of a rationalistic approach to reality, the ancients had long understood eros as the basic stuff of the universe, the mystical element of all existence. Mystical theologian Matthew Fox gives us the following insight in his work, The Coming of the Cosmic Christ: "Eros belongs at the heart of worship, at the heart of our cosmology. Our lives are as erotically humorous as they are divinely tragic" (218). In other words, the way we relate to the universe essentially includes a sense of the sacred in everything to which our soul is oriented in earnest longing for its fulfillment. This is eros.

James Mohler in his classic work Dimensions of Love (in which he categorically calls Augustine the "philosopher of love") explains the role of eros in the reality of the soul: "It is eros which gives the soul its drive toward the heavenly. With the aid of eros the soul rises upward toward the beautiful, reversing the order of descent" (135). Max Scheler notes too the cosmic background of eros, which he finds helpful in arguing for an ethics of sympathy. For Scheler, eros is the driving force of all ethical life. In The Nature of Sympathy, Scheler derives the ethics of sympathy from the cosmic eros in this way: "Eros animates the entire universe from material to the divine, and sustains it, grappling with valiant rivalry, in a ferment of life. ... Eros is the ultimate prime mover of the universe itself" (83). From this cosmic order of eros comes the life principle that defines the complexity of human life. According to Pierre Teilhard de Chardin, in The Heart of Matter, eros is our life stuff. He writes, "Love (eros) underlies so many things that 
matter to the human person, his salvation or his loss; it is the very stuff, maybe, of all our important desires" (219-20).

In any discussion of eros, Sigmund Freud will always, without a doubt, be a force on this regard. Freud defines eros in Beyond the Pleasure Principle as the "instinct towards perfection" (78). The instinct towards perfection, understood as the capacity to become what one ought to be, in the face of inherent limitations, implies the drive to survive. The inner drive to survive-in this life and beyond-is our will to existence (hence, more primordial than Nietzsche's influential "will to power" is the "will to live!").

Erich Fromm also asserts the underlying positive element of eros, viz., freedom or liberation from social expectations. "Sexual desire is one expression of independence that is expressed very early in life (masturbation)" (67), he writes in To Have or to Be? Issues of human sexuality can therefore be transformed as issues of individual struggles for liberation from a constructing or constricting social discourse.

Interestingly, Freud's theory of eros has been developed by social theorists to advance a philosophy of society which deals with the organization and perpetuation of social consciousness. Herbert Marcuse's unique revisionist account of Freud's theory of eros as fundamentally a life instinct interprets society as a process that is moving towards its apex of civilization. In the influential work Eros and Civilization, Marcuse appropriates Freud thus:

Being is essentially the striving for pleasure. This striving becomes an 'aim' in the human existence: the erotic impulse to combine living substance into ever larger and more durable units is the instinctual source of civilization. (125)

From all this, we can gather that eros is reality's motion towards perfection. Everything yearns for and moves towards the accomplishment of its being. Ultimately, eros is a cosmic impulse that pervades the whole of existence, including the life of society. Specifically, this pertains to society's gradual development through its means of relation and production. It has to produce to ensure its existence. Recent attempts to link the Freudian assertion to explicit socio-political issues like capitalism have gained ground, leading the exploration of other approaches to political questions. Following this effort, Gilles Deleuze and Felix Guattari make the following claim in their collaborative work Anti-Oedipus: "There is only desire and the social, and nothing else" (31). Desire has production as its goal. Returning to the cosmic 
and ethical dimensions of desire above, the goal of eros is transcendence that opens up or produces new opportunities of becoming.

Søren Kierkegaard, reflecting on the meaning-drivenness of human life, asserts that "[a]ll existence-issues are passionate, because existence, if one becomes conscious of it, involves passion" (226). The human person's ability to bear and suffer life requires passion, which enables one to live life to its fullest in love. Achieving human flourishing through a life of philosophy means making progress in the way we understand the many variations of love, and in understanding the role it plays in human existence. In other words, a philosophical life reveals a life that is felt, shared, and lived to its fullest. Thus, philosophy as completely erotic in terms of a relentless search for truth must continue to inspire various fields of research. For that is the function of research; its task is the investigation, generation, and dissemination of truth.

Michel Foucault in The Use of Pleasure asserts:

The relation of the soul to truth is at the same time what founds Eros in its movement, its force, and its intensity, and what helps it to become detached from all physical enjoyment, enabling it to become true love. (88)

Following the ancient conception of philosophy as love of wisdom, this establishes the interpretation of the human person as a desiring being who is solicitous of what is truly real. That certainly has significant effects on one's way of life. That is what philosophy means in practice.

A life of philosophy means a process of constant transformation. In his penetrating study of antiquity, Foucault discovers a startling find that can force others to rethink the way they do philosophy today. In The Hermeneutics of the Subject Foucault reassesses the meaning of philosophy, in the light of the ancient's practice of philosophy:

There can be no truth without conversion or a transformation of the subject. This conversion may take place in the form of a movement. Let us call this movement, .. the movement of eros (love). (15-16)

The relation of eros to philosophy is an essential constitution of philosophy itself. The question of truth cannot be dissociated from desire that seeks to find something transcendent, beyond the desiring person. This makes philosophy the most erotic human activity, since it suggests a most intense interest in and passion for the truth. In this sense, philosophy can be described as a "hermeneutics of desire." 


\section{AUGUSTINE AND THE RESTLESS SEARCH FOR HAPPINESS}

According to the Greek myth, human beings were originally round and whole, until they were cut into two halves by Zeus as punishment for their arrogance. Since then, each member of the species would look for its lost other half. As a result, human beings became desiring beings in search of their other halves. Thus the word "sex," etymologically-speaking, meant having been cut. Through this myth, we see the rise of the erotic existence of the human person, making one a being who desires happiness-for happiness is the state of completeness. Concomitantly, the self goes through a process of experiencing a discordant personality or a divided self as one seeks out the other.

Emmanuel Levinas further clarifies this insight in Ethics and Infinity: "The pathos of the erotic relationship is the fact of being two, and that the other is absolutely other" (66). Eros, then, is the human condition of being a desiring being, oriented towards the infinitely other from whom the self will always be distant. Levinas consistently stresses that the relationship with the other is a relationship characterized by the other's insurmountable alterity towards which one's identity can only be desirous. This relationship is a mystery. Elsewhere in his writings, Levinas describes this mysterious relationship as an erotic one. As he writes in Time and the Other, "[t]he relationship with the other is a relationship with a Mystery. ... Eros, strong as death, will furnish us with the basis of an analysis of this relationship with mystery" (43).

Levinas pursues this interpretation throughout Totality and Infinity, where he describes eros as the capacity of the human person to seek outside of his own interests towards reaching the impossible. He writes: "Eros is not accomplished as a subject that fixes an object, nor as a pro-jection, toward a possible. Its movement consists in going beyond the possible" (261). Simply put, eros speaks of the human person's capacity for transcendence.

In his classic work, The Varieties of Religious Experience, William James recognizes Augustine's work as paradigmatic of seeking the unity of the self out of the existential tension experienced within. James writes, "Saint Augustine's case is a classic example.... Augustine's psychological genius has given an account of the trouble of having a divided self which has never been surpassed" (171-72). Paul Ricoeur affirms the reality of the human experience of a restless heart described by Augustine. In Fallible Man he describes this existential mood: "The 'heart', the restless heart, would be the fragile moment par excellence. All the disproportions [that] 
Asian Perspectives in the Arts and Humanities 3.1 (2013): 1-21

culminate in the disproportion of happiness and character would be interiorized in the heart" (124).

By the "divided self" we surmise further here the profound failure of the human person to love what should be loved; that is, the self-betrayal to do what should be done and thus to become what one should become in reference to one's search for genuine peace or happiness. This weakness carves out a basic divide in one's will, until one resolutely returns to one's good sense. As Augustine put it, "[l]ate have I loved Thee, O Beauty so ancient and so new; late have I loved Thee!" (Confessions X: 27).

Highlighting Augustine's relevance to the study of eros is Robert O'Connell's assessment:

Few books have done more than the Confessions to shape the sensibility and fashion the subjective world of western Christianity-to elaborate its mighty images, articulate its religious moods, express its instinctive feeling for life, for man, and for man's historical adventure. (190)

Martha Nussbaum is even more candid of her description of Augustine's autobiographical discourse. In Upheavals of Thought, she writes, "The Confessions is itself a deeply erotic work, a work filled with expressions of erotic tension and erotic longing" (529). Though manifestly religious in character, the above commentaries show that Augustine's Confessions is an important philosophical model of understanding the dynamics of the self in search for itself in the other.

Understanding the dynamics of the self can also be understood as a hermeneutic of the self. In practice, the hermeneutic of the self requires reading or interpreting oneself through the narratives one strives to understand. In doing so, one brings about a renewed understanding of oneself. Arguably, Augustine's Confessions can be viewed as part of this tradition of hermeneutics, as a model for developing a narrative understanding of oneself. As Alasdair MacIntyre accurately observes: "The paradigmatic record of such a discovery (that is, a narrative understanding of oneself in the texts one is reading) was Augustine's Confessions" (83). Augustine's Confessions is a testimony of the self's bearing witness to the light of truth, whereby the self, through an incessant search for intermediate ends, is ultimately caught in the unfolding of the Real.

Methodologically, Augustine's Confessions belongs to the ancient culture of the writing of the self in personal journals or diaries, with a view to the search for truth. Charles Taylor, in his most recent work A Secular Age, describes this tradition: "Autobiography-a genre in a sense pioneered by Augustine-has become one of the most prominent fields of modern 
writing" (714). Autobiographical accounts place a heavy burden on the question of truthfulness on the writer's part. Hence, autobiography is essentially an activity of reflexive truth-telling, whereby the writer engages himself with the truth of his words as he shares them with his audience.

Jacques Derrida engages Augustine's confessional truth-seeking in a new way. In On the Name, Derrida writes: Augustine speaks of "doing the truth," which does not come down to revealing, nor to informing in the order of cognitive reason. Perhaps it comes down to testifying (39). In effect, the transformative experience of truth becomes a profound source of aesthetic delight, intellectual joy, and spiritual renewal for the human person.

The desire to be happy is a universal human experience. Without mentioning the word, Immanuel Kant, in his Critique of Practical Reason, expresses the core of the issue of eros as follows:

To be happy is necessarily the wish of every finite rational being, and this, therefore, is inevitably a determining principle of its faculty of desire. For we are not in possession originally of satisfaction with our whole existence-a bliss which would imply a consciousness of our own independent self-sufficiency-this is a problem imposed upon us by our own finite nature, because we have wants, and these wants regard the matter of our desires, that is, something that is relative to a subjective feeling of pleasure or pain, which determines what we need in order to be satisfied with our condition. (24)

In light of this, Augustine provides us with a succinct formulation of eros and the search for happiness: "What is it that I love when I love you?" (Confessions X: 7). As narrated in his Confessions, Augustine had turned to the joys of the world, including fame before the eyes of men and the pleasures of the flesh, in his quest for true happiness, but found these to be ultimately fleeting. Martin Heidegger, in The Phenomenology of the Religious Life, ventures this interpretation of Augustine's question of true happiness:

Augustine attempts to find an answer to this question by investigating what there is which God himself is, or what gives a 'fulfilling intuition' if he lives in the love of God, what suffices for, or saturates, that which, in the love of God, he intends. ('Cum te amo' already indicates an existential stage.) (130)

Heidegger's articulation of this existential dimension of Augustine's search for happiness follows the ontological import of the formal structure 
of every question. In Being and Time, Heidegger formulates this structure as follows: "Every questioning is a seeking. Every seeking takes its direction beforehand from what is sought. Questioning is a knowing search for beings in their thatness and whatness" (3).

With Augustine, his questioning and searching was directed towards the depths of one's being, struggling to free itself from its own strife. Hence, when his searching was directed outside the self, it left him feeling wretchedly empty. Thus, Augustine's searching-and any such similar search-is reflexive in character. "In other words," write William French and Robert De Vito,

with Augustine one can observe a shift toward a "radical reflexivity" grounding a sense of interiority, insofar as what becomes decisive epistemologically is not the direction of one's attention to the world but rather attention to one's activity as a thinking person, the act of knowing oneself. (27)

Simply put, one must admit to oneself the motive for searching and discover the real value of such a search to one's life. No object of one's search can therefore be left untouched.

Augustine's prayerful dialogue in his Confessions calls for a renewed understanding of self-reflection. Applying his genealogy of thought to Augustine, Michel Foucault makes the following point in The Use of Pleasure:

When Saint Augustine in his Confessions recalls the friendships of his youth, the intensity of his affections, the pleasures of the days spent together, the conversations, the enthusiasms and good times, he wonders if, underneath its seeming innocence, all that did not pertain to the flesh, to that "glue" which attaches us to the flesh. (40)

Curiously, in the case of Augustine, what was tangibly erotic proved to be eristic as well, since his justification for his indulgence in sexual promiscuity came from his blind reasoning. "Give me chastity and continence, but not yet," narrates Augustine (Confessions VIII: 7, 18). Augustine makes an equally bold admission in the dialogue "The Happy Life," which depicts his inner struggle with his unbridled attachment to the flesh:

The enticements of a woman and of fame kept holding me back, I confess, from flying immediately into philosophy's embrace, so that not until I had satisfied my desire for these did I-and this has been granted only 
to the most fortunate few-under full sail and with all oars pulling make that harbor quickly and there find rest. (64)

In his first encyclical Deus caritas est [God is Love], Pope Benedict XVI, a professed reader and admirer of Augustine, provides an eloquent account of the question of eros as a necessary background to the genuine understanding of love as a fundamental human experience: "Evidently, eros needs to be disciplined and purified if it is to provide not just fleeting pleasure, but a certain foretaste of the pinnacle of our existence, of that beatitude for which our whole being yearns" (10). Pope Benedict XVI's call to discipline eros can therefore be understood as the education of our desires, of which the control of our appetites is one concrete mode.

Educating our desires essentially means learning to direct our will towards its rightful object. The education of the will is at issue here. For Augustine, the whole point of the moral quality of desire lies in the object to which it aims. In The Education of Desire, Tom Gorringe speaks of the necessity of forming our imagination, that is, the will, according to its real object, God: "God, or the true, good and beautiful, is what desire strains towards. . Education is the recognition that the imagination only flourishes when it is trained, pruned, disciplined, and that it requires a goal" (91). The will's directedness to the good as its object must be consciously led to pursue the source of all goodness, who is God. This expresses our human desire for that reality which we believe completes our fragile existence. In addition, though we may know the right choice, it is not always easy to make that choice. Thus, how we manage our desires is a test of our maturity as human beings. Spiritual writers Fran Ferder and John Heagle put it this way:

Most of us manage eros in the tension between private needs and spiritual tasks, between the desire for pleasure and the demands of responsible relationships.... [Our experience of eros] signals our yearning for human contact and ultimately for communion with God. In the end, all artistic creation, scientific discovery, philosophical insight, theological awareness, and human relationships arise from the passion for knowledge and expression. (95-97)

Since plumbing the depths of our intimate feelings can disclose our ultimate being, Paul Ricoeur qualifies any suggestion of a philosophy of the heart or of feeling. Ricoeur points out: "If a philosophy of feeling is possible, it is a feeling which should express the fragility of the intermediate being that we are" (125). The philosophy of the restless heart is a 
philosophy that profoundly accepts the limitations of the human situation and strives to anchor it on the revelation of truth.

The search for truth is the moving force that keeps one's being restless yet ever hopeful for a final destination. Is this then a discourse on the afterlife? For Augustine and his interpreters, hope is not necessarily of the afterlife. Rather, it permeates the everyday affairs of human beings. There is hope in every moment of one's life, in one's relationships, in one's work, and in one's God! Making do with the scarce resources we have, in order to improve our present lot, with no guarantees for the future, is hope in action. The reality of hope in human life puts in question the Cartesian illusion of certitude that continues to tempt the scientifically-inclined mind today. In The Phenomenology of the Religious Life, Heidegger formulates a contemporary philosophy of life, noting how Augustine long before had already set a precedent for confronting the uncertainties of life:

'Vita' (life) is no mere word, no formal concept, but a structural complex which Augustine himself saw-without, however, yet achieving sufficient conceptual clarity. Today, this clarity has still not been attained, because Descartes moved the study of the self as a basic phenomenon in a different, falling direction. Modern philosophy in its entirety has not been able to rid itself of this. (226)

Etienne Gilson makes a judicious interpretation of Augustine's search for happiness in God. Gilson, in The Christian Philosophy of Saint Augustine, writes:

Our whole search is directed towards a necessary, immutable, eternal being; a being which has no superior and which is, consequently, God. It is not enough, then, to transcend man to reach such a being. We must transcend something in man which is such that only God can lie beyond it. Now only one possible path is open to one engaged in such a search, viz., that by way of truth. (15)

However, for Augustine, the search for God happens as a lifelong pursuit that demands an integral approach. What is this approach, considering there are counterfeit "philosophies"? "There are some who may lead others astray by means of philosophy, coloring and falsifying their errors with the great, and beauteous, and honest name" (Confessions III: 4, 8). Against philosophies that deny the place of fundamental openness to the Transcendent, it is an approach that submits the light of reason to the eternal wisdom of Revelation. This is the framework of "faith seeking understand- 
ing," definitive of Medieval culture, which led to the rise of universities as sites of the expansion of Christianity as a "philosophy" of the times.

The dialogue between faith and reason puts the human person at the center of all learning. The human person, as a believing being, is also a thinking being whose integration defines his/her own existence. As Augustine asserts, "[l]et us turn ourselves only to a search for the truth" (Confessions VI: 11, 19). Even in the contemporary world, thinkers like Charles Taylor discover in Augustine the path towards God through the inward movement towards oneself. In The Ethics of Authenticity, Taylor writes that Augustine "saw the road to God as passing through our own reflexive awareness of ourselves" (26-27). In his widely popular work Sources of the Self, he similarly states that "Augustine is the originator of that strand of Western spirituality which has sought the certainty of God within" (140).

This sense of interiority links our subjectivity to the Infinite. God becomes clearly beyond the knowing search of the subject, as the reality of God surpasses all human attempts to comprehend Him. As a result, Taylor asserts in The Ethics of Authenticity, "[t]he properly 'Augustinian' intuition, [can be formulated, thus]: we can only understand ourselves if we see ourselves as in contact with a perfection which is beyond us" (140). Yet, it remains that the only way to the Infinite is through our finite existence. Gilson affirms Taylor's assertion: "Augustinism recognizes as true only that philosophy which is not satisfied to point out the end but provides the means of reaching it" (243).

Theologian Hans Urs von Balthasar is the most articulate on this regard. According to him, God is the real find that must be sought over and again-an assertion we have seen in Augustine's work. In his meditation on the Church Fathers, von Balthasar describes Augustine as follows:

Augustine, the greatest of all seekers, and finders, would be the last to have something to say to a complacent possession without any question. For him God is not only here below but eternally the one to be sought ever anew-even in having found. (387)

Within the Neo-Platonic perspective which framed Augustine's thought, this implied that philosophy, which essentially constitutes rational life, is a journey towards our "home," where we can find final solace for our finitude. For Augustine, philosophy is a rule of life governing the search for happiness. Quoting Augustine's "The Happy Life," philosophy is a journey "back home and to a most welcome rest" (62). Out of our finitude arises an inescapable experience of our existential inquietude, which stirs and moves us to question ourselves and to go beyond our given situation. 
In light of all this, we see that being human therefore is a process of constant striving for perfection in the context of integral relations. Simply put, being a self implies seeking out the other, because personal integration with the other through mutual positive interaction, in view of the truth, is the source of real happiness. "Joy in the truth is the happy life," asserts Augustine (Confessions X: 23, 33). Gilson's in-depth study of Augustine brings the matter to the fore even more strongly: "Man has no reason to philosophize except with a view to happiness.... Philosophy therefore teaches men how to be happy" (62).

\section{CONCLUSION}

"He who tries to promote human knowledge and insight is destined to always encounter the opposition of his age," Arthur Schopenhauer (144) wisely reminds us. When faced with questions of whether our present attempt to philosophize on love, sex, or eros is anachronistic, even irrelevant, to our contemporary, practical issues in these uncertain times, we can answer with a no. Philosophy, as we have seen in this work, is a process of growth integral to self-development regardless of the mundane affairs that catch our attention in the contemporary world.

There is much positive value to draw from the greater understanding of our sexual or erotic constitution that we have seen above. On the basis of this, therefore, we must examine our interpretations of ourselves, especially those interpretations that are mediated through education. As Kant wrote, "[e]verything in education depends upon establishing correct principles, and leading children to understand and accept them" (108), reminding us that education is crucial in shaping a society's mindset. Part of the better understanding we have gained of eros impels us to help others better understand that our sexual constitution is integral to our being human persons. Augustine's thought can help us surpass narrow ways of thinking about sex, ways which damage the integrity of our being.

Augustine's philosophy also reminds us that restlessness, emptiness, angst, etc., reveal the human person's directedness towards union with the other, ultimately finding rest and peace in returning to the origin of existence, that is, God. "You have made us for yourself, and our heart is restless until it rests in you." Or, as Don Cupitt expresses it in more contemporary terms,

God is the pearl of great price, the treasure hidden at the center of the religious life... .God is the mythical embodiment of all that one is con- 
cerned with the spiritual life. He is the religious demand and ideal, the pearl of great price and the enshriner of values. (178-80)

In short, no existential ontology that gives an adequate interpretation of the human situation is possible without turning to the God-question. The God-question cannot be ignored or dismissed, if we are to understand sexuality in its essential sense. Sooner or later it will have to be reckoned with as an essential component of the meaning of being human, no matter how difficult this may be. Heidegger explains this difficulty, reminding us that "[g]enuine love of God has the sense of wishing to make God accessible to oneself as the one who exists in an absolute sense. This is the greater difficulty of life" (Phenomenology of the Religious Life 221). It is a question that radicalizes the entire concept of being human in a universe that is hoped to be a home to every human being.

The preceding discussion, we maintain, requires that we come to terms with the truth that sexuality is the human person's mode of relating to the world, in his/her capacity as an embodied being. More importantly, how we regard our sexuality essentially reflects the way we relate with one another. As a modality of human existence, it is in and through sexuality that we experience ourselves, others, and the world. Surely, sexuality as our "being-in-the-world" should be a source of happiness. We should be grateful for and celebrate our sexual selves. We should realize how our own honest sexual preferences can bring us to a level of objectivity, that is, to a rational acceptance of who we are.

However conceived or argued, human existence is not an absolute life. It is a life of desire, of hope, and of love, which all pertain to a seeking for what is not yet. In the end, Augustine's philosophy and theology of eros participates in an eschatology that envisions human sexuality from the perspective of eternity. In the end, no spirituality is genuine unless and until it is deeply rooted in a profound understanding of one's sexuality. "And God saw everything that he had made, and, behold, it was very good" (American Standard Version, Gen. 1.31).

\section{WORKS CITED}

Arendt, Hannah. Love and Saint Augustine. Chicago: U of Chicago P, 1996. Print. Augustine. "The Happy Life." Augustine of Hippo: Selected Writings. Ed. Emilie Griffin.

Trans. Mary T. Clark. New York: HarperCollins, 2006. 163-94. Print.

---. The Confessions of Saint Augustine. Trans. John K. Ryan. New York: Doubleday, 1960. Print. 
Asian Perspectives in the Arts and Humanities 3.1 (2013): 1-21

Benedict XVI. Deus Caritas Est: Encyclical Letter on Christian Love. Pasay City: Paulines, 2006. Print.

Bloom, Allan. Love and Friendship. New York: Simon and Schuster, 1993. Print.

Cupitt, Don. Taking Leave of God. London: SCM, 2001. Print.

De Chardin, Pierre Teilhard. The Heart of Matter. Trans. Réne Hague. San Diego: Harcourt Brace, 1979. Print.

Deleuze, Gilles, and Félix Guattari. Anti-Oedipus: Capitalism and Schizophrenia. Trans. Robert Hurley, et al. New York: Continuum, 2004. Print.

Derrida, Jacques. On the Name. Trans. John P. Leavey. Ed. Thomas Dutoit. Stanford: Stanford UP, 1995. Print.

Ferder, Fran, and John Heagle. Tender Fires: The Spiritual Promise of Sexuality. New York: Crossroad, 2002. Print.

Foucault, Michel. The Hermeneutics of the Subject: Lectures at the Collège de France (19811982). Trans. Graham Burchell. Ed. Frederick Gros. New York: Picador, 2005. Print.

---. The Use of Pleasure: The History of Sexuality 2. Trans. Robert Hurley. New York: Vintage, 1990. Print.

Fox, Matthew. The Coming of the Cosmic Christ: The Healing of Mother Earth and the Birth of the Global Renaissance. New York: HarperCollins, 1988. Print.

Frankl, Viktor. Man's Search for Meaning. New York: Pocket, 1985. Print.

French, William C., and Robert A. De Vito. "The Self in Context: Issues." The Whole and Divided Self: The Bible and Theological Anthropology. Eds. David E. Aunne and John McCarthy. New York: Crossroad, 1997. 23-48. Print.

Fredriksen, Paula. "Historical Integrity, Interpretive Freedom: The Philosopher's Paul and the Problem of Anachronism." St. Paul Among the Philosophers. Eds. John Caputo and Linda Martin Alcoff. Bloomington: Indiana UP, 2009. 74-86. Print.

Freud, Sigmund. Beyond the Pleasure Principle. Trans. James Strachey. New York: Bantam, 1963. Print.

Fromm, Erich. To Have or To Be? New York: Harper, 1981. Print.

Gaarder, Jostein. Vita Brevis: A Letter to Augustine. Trans. Anne Born. London: Phoenix, 1997. Print.

Gilson, Etienne. The Christian Philosophy of Saint Augustine. Trans. L.E.M. Lynch. New York: Random House, 1960. Print.

Gorringe, T.J. The Education of Desire: Towards a Theology of the Senses. London: SCM, 2001. Print.

Heidegger, Martin. The Phenomenology of the Religious Life. Trans. Matthias Fritsch and Jennifer Anna Gossetti-Ferencie. Indianapolis: Indiana UP, 2004. Print.

--- Being and Time. Trans. Joan Stambaugh. New York: State U of New York P, 1996. Print.

Holler, Linda. Erotic Morality: The Role of Touch in Moral Agency. New Brunswick: Rutgers UP, 2002. Print. 
Jeffrey Centeno, "Towards an Existential Ontology of Eros in Augustine"

James, William. The Varieties of Religious Experience: A Study in Human Nature. Ed. Martin

E. Marty. Middlesex: Penguin, 1985. Print.

Kant, Immanuel. Critique of Practical Reason. Trans. Thomas Kingsmill Abbott. Mineola: Dover, 2004. Print.

---. On Education. Trans. Annette Churton. Mineola: Dover, 2003. Print.

Keen, Sam. The Passionate Life: Stages of Loving. New York: Harper, 1983. Print.

Kierkegaard, Søren. The Essential Kierkegaard. Ed. Howard V. Hong and Edna H. Hong. Princeton: Princeton UP, 2000. Print.

Laing, R.D. The Divided Self: An Existential Study in Sanity and Madness. Baltimore: Penguin, 1970. Print.

Levinas, Emmanuel. Time and the Other. Trans. Richard A. Cohen. The Levinas Reader. Ed. Seán Hand. Oxford: Blackwell, 2007. Print.

---. Ethics and Infinity: Conversations with Philippe Nemo. Trans. Richard A. Cohen. Quezon City: Claretian, 1985. Print.

---. Totality and Infinity: An Essay on Exteriority. Trans. Alphonso Lingis. Pittsburgh: Duquesne UP, 1969. Print.

MacIntyre, Alasdair. Three Rival Versions of Moral Enquiry: Encyclopedia, Genealogy, and Tradition. Notre Dame: U of Notre Dame P, 1990. Print.

Marcuse, Herbert. Eros and Civilization: A Philosophical Inquiry into Freud. London: Routledge, 1998. Print.

McNeill, David N. "Human Discourse, Eros, and Madness in Plato's Republic." The Review of Metaphysics 60.2 (2001): 235-68. Print.

Mohler, James A. Dimensions of Love: East and West. New York: Doubleday, 1975. Print.

Nussbaum, Martha C. Upheavals of Thought: The Intelligence of Emotions. Cambridge: Cambridge UP, 2003. Print.

O' Connell, Robert J. St. Augustine's Confessions: The Odyssey of Soul. New York: Fordham UP, 1995. Print.

Rahner, Karl. "Behold the Heart: Preliminaries to a Theology of Devotion to the Sacred Heart." Theological Investigations 3. New York: Seabury, 1974. 321-30. Print.

Rescher, Nicholas. Philosophical Standardism: An Empiricist Approach to Philosophical Methodology. Pittsburgh: U of Pittsburgh P, 1994. Print.

Ricoeur, Paul. Fallible Man: Philosophy of the Will. Trans. Charles Kelbey. Chicago: Henry Regnery, 1965. Print.

Sartre, Jean-Paul. Being and Nothingness. Trans. Hazel E. Barnes. New York: Washington Square, 1992. Print.

Scheler, Max. The Nature of Sympathy. Trans. Peter Heath. London: Routledge, 1954. Print.

Schopenhauer, Arthur. The Basis of Morality. Trans. Arthur Brodrick Bullock. Mineola: Dover, 2005. Print.

Taylor, Charles. A Secular Age. Cambridge, MA: Belknap P of Harvard UP, 2007. Print. 
Asian Perspectives in the Arts and Humanities 3.1 (2013): 1-21

---. Sources of the Self: The Making of the Modern Identity. Cambridge: Cambridge UP, 1992. Print.

---. The Ethics of Authenticity. Cambridge, MA: Harvard UP, 1992. Print.

Tillich, Paul. Love, Power, and Justice: Ontological Analyses and Ethical Applications. London: Oxford UP, 1960. Print.

von Balthasar, Hans Urs. "Saints in the Church." The von Balthasar Reader. Eds. Medard Kehl and Werner Löser. Trans. Robert J. Daly, SJ and Fred Lawrence. New York: Crossroad, 1997. 376. Print.

Jeffrey Centeno is director of the Planning, Quality Assurance, and Communications Office (PQACO) at Saint Louis University, Baguio City (Philippines). He obtained a PhD in philosophy with a dissertation on educational philosophy at De La Salle University-Manila in 2008. His research interests include philosophy of education, philosophy of the human person, educational management, and organizational strategic planning. He teaches in the graduate school of education at Saint Louis University. 